\title{
Noise: The Political Economy of Music
}

\section{(Author: Jacques Attali, 1977, 1985, 2009, 2011)}

Firmansah

Mercu Buana University, West Jakarta, Indonesia

Jacques Attali - French economist who suggests a number of theories about the political economy of music in some editions of this book. His main thesis is that the change of basic character of music along history have indicated a fundamental revolution in political and economic structures. He concludes inductively that the change which occurs in music in this time predicts the future shape of our society.

The part of this book will cause a strong controversy among the readers, because the historical argument integrates with political collision in this time period. His arguments are arranged by four types of music which he considers as a fundamental aspect: "sacrifice", "representation", "repetition", and "composing". Although these four types have emerged sequentially in history, they have not replaced each other; each of them overlaps and mixes with the previous one. Creating the role of music in society is more complex. Every readers who are interested in the fate of music in the 21st century, will find Attali's book as a good starting point for further investigation.

Fundamental terms have a special meaning in Attali's argument. On the aspect of "sacrifice," it refers to Rene Girard's concept that the ritual sacrifice which is made in the earliest human societies to distribute and replace the general violence that on the contrary will tear it. His assumption that the majority of the ancient people lives in the terror of identity. This fear creates a desire to imitate, it creates competition, and thus uncontrollable violence that spreads like a plague. For controlling this threat, communities are forced to appoint scapegoats, which are actually or symbolically sacrificed to distribute this potential violence. The effect, hierarchy and stable society can be established.

How does music connect with this process? Attali states that noise is violence. Making noise is disturbing a transmission, disconnecting a relationship, killing. 
This is a murder simulacrum. Then, music is channelization of noise, the way to control and defeat noise by creating a harmonious order in the field of noise. By doing this, it helps to sustain and legitimize the social order in general, although the presence of noise or difference opinion in the margins of society can never be completely eliminated.

However, Attali does not seem to believe that there is a fundamental change in music from this early period that takes action as a substitute for sacrifice until the emergence of capitalism in the end of medieval century and early Renaissance Europe. He sees the transformations of explorers and agitators who wander into royal singers and musicians. One of the earliest examples of change from feudalism to capitalist economy and called it as the stage of "Representation." In the next part we will investigate the analyzing of the intention of Attali.

The historical changes in music have presented a system of political economy. What happens in music can predict the power systems in society. In connection with that, Attali gives a point of view about the political economy of music. According to him, music runs parallel to the society both the structure and all the changes occur, thus music like mirrors and prophecies to see the society. If you can see how the music is led, then you can see how the society is led.

A musician in a feudal society, as a minstrel or functionary. They are valets/ servants with an employment contract part of a relationship of domestication and not an economic exchange. Do not receive royalties or payments in any way when their work is played. Producing music according to the orders of the nobility who have the right to use, the right of ownership over musicians and music.

The characteristic of music formed in feudal society has the concept of natural harmony which is applied by the controller. This idea places the rhythm and voice register as something that has the effect of soul castration of society to create the social order of the belief system. The distribution of music is usually only in the kingdom, place of worship or concert hall of the nobility. As a political tool, music is an implicit pride as scripture is dedicated to explicit breeding. Harmony in music becomes the organizer of the noise/violence, maintaining the social order, becoming a sign as well as the meaning of peaceful. Music as a reminder that musicians are slaves of nobles, gifts to controllers.

Approaching the industrial revolution of the 18th century, music does not to be a support again for the power of feudal society. Musicians want artistic autonomy in their work. However, to do that, their work must depend on the monetary value and the parties who want to pay for the production of his work. Musicians come out from feudal environments to earn a living by playing in concert halls. This is the political form of the bourgeoisie, making themselves the members of the artists against the powers of feudalism. Changing the system of production and distribution of music through economic ideology to artists as a weapon against the feudal society. 
The musicians before the industrial revolution are under the authority of the nobility, finallyfree but still do not have autonomy over his work. Depending on concert tickets and number of score copies which are produced in exchange for money. Guiding music into monetary value means money being the laborof composers and players. The middle class appears like composers, publishers and tickets entrepreneurs to watch the show. Music is used as a tool to present ideology in the social order of society that is money as a representation of all values.

Music becomes a commodity, not only valued by natural harmony but shaped by a controller through an aesthetic and theoretical basis. Unifying the relationship between the welfare of the musician and the rationalization of science. Until forming a complexity level, complexity of harmony through a combinatorial system, orchestration system and instrumentation for the standardization of the spectacle which further earns the exchange rate. The impact of that thing is that music becomes the object of the rule monopoly and the contradictions of capitalist economic system.

For controlling that matter, a copyright law policy is created that seems to protect the rights of the artist. However, in reality, this policy is applied only as a capitalist tool against feudal power. It is only since the industrial revolution that the power of the state gives copyright to artists as independent entrepreneurs to oppose the monopoly of the capitalists. It is also implemented the policy of nationalizing music by rearranging the mechanism of production and its distribution.

The policy is intended to release music from the use of the value of spectacle by capitalists for gaining profit. This is a voluntary project for the elaboration of state ideology and standardization of cultural production. Artists produce mars music, hymns, patriotic songs are used to build the spirit of nationalism. Musicians work as forced labor, having to create a large number of musical works as a service to the state.

Music becomes a political and economic tool by the controller. The use of the musical spectacle value for politics and economic exchange that occurred is far from the desire of musicians in which have autonomy in his work. First, musicians in the feudal environment as servants/slaves create music to glorify and legitimize the power of God even the king. Second, copyright forms a monopoly over production, not protection for composition or control over musical representation. The concert hall becomes a new site of violent disguise: the price of concert tickets for viewers does not match with the value of the composer's labor and the player, cannot relate to the amount of time producing a work with an acceptable exchange rate.

Afterwards, thirdly, the policy of nationalization in music means transferring the ownership of music to the state. Returning to political control toward music 
makes it more extreme than the practice of feudal power. From this, it indicates the policy of use and exchange of values in music has been deviating from the beginning. The normalization of policy through music means getting people to believe in a new social order through what they hear.

Attali gives his opinion that in this representation the arena of the political economy of the controller takes place. By involving parallel developments in music that develop into commodities and also the development of harmony in music. Moreover, the flow of music production and distribution is all regulated by the controller for economic gain, perpetuating the political power and creating the social class. Music becomes the locus of theatrical representation of the social order of society. It largely explains that representation is the use of spectacle values that imply power through exchange for the economy and the development of harmony in music.

According to the explanation, Attali supports his argument with many interesting references on music history. By the invention of recording and broadcasting, emerges the next important form of musical activity, which he calls "repetition." In this time, the technique of industrial revolution becomes acceptable to music; mass-produced in millions of copies to be consumed by individuals in their privacy domain. This tendency becomes a commodity like any other merchandise. For keeping the music industry goes consistently, it is needed a huge effort to keep demand of commodity records which flows from factories. Not only in popular music, but also on a great level in classical music.

Then, Attali presents his vision of the future in a fundamental aspect which is called "composing." The use of the word composing is the activity in which the musician plays primarily for himself, outside the spectacle operation or the accumulation of value. When the music breaks away from the aspect of sacrifice, representation, and repetition, it appears as an activity that ends in itself, that creates its own aspect at the same time with work. Attali awaits a radically changed society in which all activities are free from the rule of capitalism. Releasing from the image of future utopias that are available in music.

When reading Attali's book, it must be remembered that this book is published in several editions $(1977,1985,2009$, and 2011). That possibility is based on the phenomenon of the political economy of music that still continues as discusses in this book. The question is then - what does Attali's goal has happened to the presently context. Especially about all the possibilities of rapid technological development. Whether music is only able to arrive at the "repetition" aspect. Or, "composing" aspect only able to be part of the image of future utopias. 